Music-Making, Ritual, and Gender in a Southeast Asian Hill Society

Author(s): Kenneth M. George

Source: Ethnomusicology, Vol. 37, No. 1 (Winter, 1993), pp. 1-27

Published by: University of Illinois Press on behalf of Society for Ethnomusicology

Stable URL: http://www.jstor.org/stable/852242

Accessed: 11-02-2016 05:29 UTC

Your use of the JSTOR archive indicates your acceptance of the Terms \& Conditions of Use, available at http://www.jstor.org/page/ info/about/policies/terms.jsp

JSTOR is a not-for-profit service that helps scholars, researchers, and students discover, use, and build upon a wide range of content in a trusted digital archive. We use information technology and tools to increase productivity and facilitate new forms of scholarship. For more information about JSTOR, please contact support@jstor.org. 


\title{
Music-Making, Ritual, and Gender in a Southeast Asian Hill Society
}

\author{
Kenneth M. GeORGE
}

HARVARD UNIVERSITY

\section{Introduction}

Istening to people making music is a way to listen in on the making of Lsocial relationships. Music does not transcend the strains of social life, but as a set of practices tuned to and tuned by the flux and flow of human relationships, it is necessarily bound to them. As social practice, musicmaking events take place within a field of cultural and historical particularities. Yet because they are always immersed in human situations, musics also bear the sound and signature of symbolic power and social hierarchy (see Attali 1985, Bourdieu 1991, Feld 1984, and McClary 1989, 1990). Different modalities of music-making are different modalities for exercising social and cultural power, for shaping, challenging, and negotiating relationships of authority and domination. Who performs, who listens, who is silenced, and who may not listen are important factors in this exercise of social and symbolic power. How music-making events shape authority and power in other dimensions of social life is critical, too. Furthermore, the reach of power and authority extends into musical sound. Rhythm, pitch and scalar relationships, melodic structures, antiphony, tempo, all the formal features of performance so often abstracted to construct a music system without regard to its social genesis or dominance in a community comprise a socially constructed and sanctioned set of dispositions and memories with which persons make music (cf. Halbwachs 1980, Schutz 1977). All of which is to say that musics will be caught up inextricably in the social divisions, hierarchies, and conflicts associated with class, ethnicity, and gender. In turn, description and analysis of musical cultures and communities must at some point confront issues of social difference, power, and authority.

This article will explore the ways in which music-making and gender differences mutually shape one another in a hill society in island Southeast Asia. The questions raised have to do with the role music-making plays in

(C) 1993 by the Board of Trustees of the University of Illinois 
producing or subverting gender-based hierarchies of prestige and authority: Does music support or threaten predominant ideas about gender? How does it shape the way in which women and men experience sexual hierarchy? Can music-making itself be a form of sexual politics? These issues are especially intriguing in light of our understanding of music and gender in the island region. As Jane Atkinson and Shelly Errington note, gender has not stood out as a dominant theme or problem in the Southeast Asian archipelago, a place where social hierarchy usually rests on principles of seniority and spiritual potency and where sexual antagonism appears muted (1990). As for music, the dominant traditions in the region-and particularly those of the hill societies-are often traditions of sacred music performed in the context of ritual. A look at case materials from Southeast Asian hill communities should shed fresh light on music-making, ritual, social hierarchy, and gender ideology in small-scale societies known for their relative egalitarian outlook and their nonstratified (or minimally stratified) social order (cf. Feld 1984, Roseman 1984).

\section{Gender in Island Southeast Asia}

Before going into the specifics of a single ethnographic case, it is helpful to take a broad look at gender relations in island Southeast Asia. A significant number of ethnographic reports from Indonesia, Malaysia, and the Philippines give the impression that despite gender differences, disparities between men and women with respect to prestige and power are culturally played down or muted among the island societies (see, for example, Freeman 1970 [1955]; Geertz 1973; Geertz and Geertz 1975; Rosaldo and Atkinson 1975). In many instances, and especially among the region's cognatic societies, local ideologies and practices place women on a fairly equal footing with men. Some societies, like the Meratus Dayak described by Anna Tsing (1987), offer ways for women to become prominent spiritual leaders, and others, like that of Negeri Sembilan, quite clearly vest women with an enormous degree of social, political, and economic autonomy (Peletz 1987, 1988). Further, there are societies, like the Wana of central Sulawesi, that emphasize the human sameness shared by women and men rather than their differences (Atkinson 1990). Shelly Errington may not be far off the mark, then, when she proposes that for many of the cultures in the region, gender is "not the difference that makes a difference" (N.d., quoted in Kuipers 1986). For this part of the world, she finds that age or seniority usually serve as the basis for social hierarchy while gender differences promote social complementarity (1990:47-53).

Errington's general remarks provide a useful compass for exploring how gender does or does not enter into the construction of sociopolitical 
hierarchy in island Southeast Asia. At the same time, some caution is called for in charting gender relations throughout the region. To begin, there are troublesome cases where social practices privilege men despite egalitarian ideologies. Among the egalitarian Temiar, for example, men enjoy a greater visibility in political and ritual spheres than women (Roseman 1987). The same is true of the Wana, mentioned above. Despite ideas about a human sameness that transcends and levels gender difference, Wana men have greater access than women to spiritual potency, and with it, greater political power (Atkinson 1990). And Tsing's more recent examination of Meratus Dayak culture reveals that men, rather than women, steer dispute settlements (1990). Historical change further complicates the picture throughout island Southeast Asia. For instance, a recent paper by Vinson Sutlive suggests that in the last twenty years disparities between Iban men and women have grown wider under the influence of urban migration (1987). More crucially, the impact of colonial regimes, nationalism, and postcolonial states on the societies in question have had important consequences for gender hierarchy and ideology at the local level.

In short, complexity and change need to be worked into the description and analysis of gender relations in Southeast Asian societies. Tsing takes up this point in arguing against the homogeneity of gender systems, urging that analysis "move beyond the search for a single set of notions of male and female linked with each culture to explore the production and use of these notions in political process" (1990:124). A similar view is at the heart of Sherry Ortner's critical look at debates about universal male dominance: "Although a given ideology and/or a given pattern of practices may be hegemonic," she writes "it is never total" (1990:78). There are inevitably nonor counterhegemonic ideas and practices that form the sites for historical change or which pose a significant challenge to patterns of domination. The problem for the analysis of gender systems, then, is to take note of multiple and oftentimes contradictory ideas and practices and to learn how they are distinguished and interrelated.

Explorations of this kind might usefully consider how music-making shapes (and is shaped by) gender ideologies and the social relations between women and men. Taking an approach that meshes well with Ortner's program for analysis, Ellen Koskoff proposes that musical performance has the potential to confirm and maintain what Ortner calls "gender hegemonies" (1990) as well as the capacity to challenge or subvert them (Koskoff 1987). Koskoff's framework for relating music and gender looks especially promising for the ethnography of island Southeast Asia. A striking number of studies from this region suggest that gender differences reach their most radical formulation and display in ritual music and speech (e.g., Atkinson 1989, 1990; Kuipers 1986; Traube 1986). Given their connection 
with the sources of spiritual potency, the gender differences that come to the fore in ritual music may prove to play a crucial role in the production or subversion of authority, power, and prestige.

In keeping with the issues and approaches sketched above, the following study explores ritual music and gender difference in a minority religious community in the western highlands of South Sulawesi, Indonesia. Specifically, discussion will concern villagers who still embrace ada' mappurondo, the ritual tradition indigenous to the ethnic region once known as Pitu Ulunna Salu ("the seven headwaters") but which is today administratively incorporated into the Indonesian state as Kecamatan Mambi. This article will not explore music in non-ritual settings, for there is none. That music occurs only in ritual, a place where differences between male and female are drawn in a radical way, suggests that it may be significant in the villagers' experience and understanding of gender. Following a thumbnail ethnographic sketch of the mappurondo community, I will take a broad look at some of the multiple practices and ideas that make up the local gender system. Thereafter, I will turn to the problem of ritual music and its relationship to gender distinctions. The emerging portrait shows the field of musical performance to be as diverse and complex as the local gender system.

\section{Ethnographic and Historical Background}

Members of the mappurondo community live in households scattered throughout a dozen or more of the villages located along the headwaters of the Mambi and Hau rivers, and number roughly thirty-five hundred to four thousand persons. ${ }^{1}$ Like their Christian and Muslim kin who comprise the majority of the region's population (about 50,000 people), mappurondo villagers usually farm rice terraces, swiddens, small garden plots, and coffee groves. Everyday activity in the village revolves around the household, the household cluster (or hamlet), and the group of relatives that make up a person's bilateral kindred. Mappurondo villagers show a striking preference for village endogamy, for marriages with second or third cousins, and for marrying their own, that is, persons who have not been lured away from ancestral tradition by Christianity and Islam. As a result, the mappurondo households in any given village make up a close-knit group of kin as well as a cohesive moral and ritual polity.

Prestige and social status in the mappurondo community rest largely on age and seniority. Persons show deference to parents, grandparents, parents-in-law, and elder siblings, and expect the same from their juniors and offspring. Seniority in descent also plays a crucial part in making successful claims to inheritable and prestigious positions of ritual leadership. 
At the same time, significant terrace and coffee holdings, ritual displays of wealth and prosperity, and the ability to convene a retinue of followers bestow prestige on a person or household. For the community, then, age and seniority tend to create a fixed set of status positions, while wealth and achievement offer a means for elevating prestige and influence. Given these two axes of prestige, a person's social status is inevitably and incessantly negotiated, contested, and kept in flux.

With the arrival of Islam in the eighteenth and nineteenth centuries and Christianity in the twentieth, upland society fractured along religious lines. Very simply, Muslims and Christians turned their back on mappurondo rituals. Their censorious attitudes and institutional clout gained further strength under the deepening influence of Indonesian state policy, a policy which insists on monotheistic religion as a keystone of progress-oriented citizenship and which effectively denies the mappurondo community legitimacy and support. As a result, followers of ada' mappurondo today comprise a minority community with a distinct ideological focus and identity. It is a religious community rather than an ethnic one.

It is worth emphasizing here that the mappurondo community exists only insofar as it holds to a tradition of ritual performance. To be mappurondo entails a commitment not only to the ancestral "pagan past," but also to ritual performance as such (cf. Hymes 1981). Struggling to remain the authoritative voice of local tradition, the community has clung to ritual as the supporting pillar of mappurondo identity and polity. Thus, ritual performance is doubly political. On one hand, it is a key arena for intravillage prestige politics. On the other hand, ritual is the most crucial political act the community can undertake for keeping ideological and practical control of the past, and with it, some control over the present.

\section{A Glimpse at the Gender System}

Generally speaking, the relations between mappurondo men and women steer toward balance and collaboration, and in many contexts may be said to be relatively egalitarian. In fact, men (muane) and women (baine) are in many ways the same. For example, both inherit equally, both strive toward industriousness, and both have voice in managing household affairs. Similarities aside, gender differences do exist and do order village life, especially in the division of labor and ritual practice. Yet most persons tend to view these differences as complementary in nature, and it is in part this perceived complementarity that keeps gender distinctions from becoming a problem in everyday life. It needs to be asked, of course, whether this complementarity has a basically egalitarian or hierarchical character. I will explore this problem in the pages that follow. For now it is important to note 
that both men and women in the mappurondo community use a discourse of complementarity to level gender differences without erasing them and to portray them as fitting, natural, and reasonable.

This egalitarian discourse appears to be the common or predominant one. To my knowledge, no one in this community claims men or women to be fundamentally superior to the other. Along with some basic ideas about human sameness, there exists a basic moral view as to what makes a "good person" (mapia penabanna, literally, "with good breath [spirit]"), irrespective of gender. Generosity, patience, and industriousness, for example, are valued in both men and women. Yet ideas about manhood and womanhood also need to be considered. In the mappurondo community, a man should have the valor and skills of a headhunter (cf. Atkinson 1990, Rosaldo and Atkinson 1975). He has a reputation to keep, and must learn to bluff or threaten others with a "don't mess with me" attitude. At the same time, a man should be able to persuade with high oratory and a sound knowledge of tradition. A woman, on the other hand, should be a skilled gardener. Villagers do not stress women's childbearing, but rather, her domestic discipline. The favor shown a woman's capacity for domestic discipline does point to a troubling current in the seemingly egalitarian relations between men and women. Exalting women for their domestic discipline is perhaps a way to celebrate their controllability. In this sense, a good woman is one who monitors her own domestic behavior and thus spares another personperhaps a husband or father-the need to rein her in.

Unlike the division of ritual activity, the sexual division of labor in the mappurondo community is flexible and relatively balanced. Women customarily plant, weed, harvest, and gather, while men till rice terraces, burn off garden plots, fish, and make homes, huts, and rice barns. Yet men and women are free to assist one another in these tasks. Childtending and cooking preoccupy women more often than men, but are quickly passed on as chores for children roughly age seven and up. The division of labor is far more rigid, however, when it comes to hunting or weaving: Without exception, hunting falls to men and weaving to women. I have no evidence that villagers place differential value or worth on these various tasks. The sexual division of labor thus appears balanced and egalitarian.

Both men and women take part in ritual life, and both have opportunity to become recognized specialists vested with the authority to perform certain ceremonial roles. Traditionally, men have had nearly exclusive hold on village political positions. It always falls to men to adjudicate local political affairs. The pattern continues today, at a time when the mappurondo community has to make concessions to the civil administration and those who have embraced Islam or Christianity. Still, women are not enjoined from bringing an issue before village men, nor are they prevented from holding 
village political office. That they seldom do so points suggestively to a potentially important dimension of hierarchy in the purportedly level field of gender complementarity.

Villagers rarely question gender differences, but more often presume their givenness and naturalness. Indeed, the givenness of an egalitarian yet differential order can be glimpsed in ideas about the supernatural, specifically the realm of the debata, or spirits. The most powerful, if remote, deity is Debata Tometampa ("one who shapes with hands"), whose primordial and genderless character suggests a projection of human sameness into the world of the supernatural. A more complex figure is the spirit known both as Debata Tomeola ("one who journeys)" and Debata Tomemana' ("one who has ancestral bequests" [i.e., hearth and rice land]). As Tomeola, the spirit is male and follows men in their activities and adventures. As Tomemana', the spirit is female and sits above the hearth watching over women and the household. More present in the world of human affairs than Tometampa, Tomeola/Tomemana' is a fusion of complementary gender differences. Most other spirits are clearly male or female. Among them, the debata bisu ("the quickening spirits") enliven villagers during ritual, bisu muane stirring men, bisu baine stirring women. Two other kinds of supernatural beings, debata buntu ("spirits of the mountains") and debata totibojongan ("spirits in the firmament") link male and female to nature and culture, respectively. Debata buntu is male, an unruly, malevolent, and insatiably hungry, red-faced spirit who dwells in the forests and threatens to disturb village order during rituals. In contrast, the girlish and easily startled debata totibojongan descend from the sky each year to coax the rice crop into maturity.

In light of the ideas and practices of everyday life, local gender differences in the mappurondo community appear to have the relatively egalitarian and complementary character one might expect in a society that uses age as the most basic criterion of prestige (Ortner 1981, 1990). Still, there are some issues about control that trouble and haunt the talk of equality, balance, sameness, and complementarity. We should go on to ask, then, what kind of sexual politics accompany this egalitarian gender ideology. Specifically, it is worth looking for points of tension and asymmetries in authority and power between men and women.

While growing up, boys and girls have much in common. They take part in many of the same tasks, and both learn a fairly uniform set of values. Gradually young people begin to form cohorts with relatives and companions of the same sex. From these cohorts both boys and girls will develop friendships lasting long into life. The hearth, rice barn, and garden soon become centers of activity for girls, while boys go off to graze livestock, collect firewood, and gather building materials. By the time they are well into 
their teens, boys are adept at the different subsistence tasks that fall to men, just as young women are skilled at the work that falls to them. As they approach an age to marry, young men are expected to have participated as warriors and orators in pangngae, the annual headhunting ritual staged by each village (see George 1989). Girls, on the other hand, should have become familiar with the dances performed in elaborate household rituals run under the authority of women.

One's adolescence usually shadows forth the sexual politics and claims to authority and power that occur later in life. But by and large, adolescence has a playful, risk-free tenor. Not a few villagers-usually men, on occasion, a woman-show a nostalgia for this period of their lives when they were relatively untroubled by prestige politics and adult responsibilities. Nonetheless, teenage years are a time when the social division of labor and friendship more or less puts young men and women into different orbits of responsibility and different arenas of prestige competition. I can offer very little about prestige struggles among young women. I suspect they are common, but would add that such concerns seldom appear to preoccupy unwed women or disrupt village life. Young men, however, are keen to be first among equals. Being honored as a headhunter is one way to claim higher status and thereby fuel the envy of one's companions. At the same time, being good at seducing unwed girls is an especially significant way to build prestige within a circle of young men. Requiring stealth and an ability to flatter and cajole, these seductions presage some of the sexual politics and prestige anxieties of adult male life. ${ }^{2}$ Central among them is a male desire (or effort) to control women.

It is marriage that brings men and women into complete adult status and binds them into a complementary relationship. As husband and wife, they become bela, a term unmarked for gender denoting a companion in a mutual task. ${ }^{3}$ In the work of running a household together, husband and wife nonetheless assume different roles and responsibilities. Beside her role as mother, a wife takes on the task of planting and harvesting gardens and rice terraces. She also manages the hearth, the granary, and her own landholdings (which are inherited at marriage). Husbands busy themselves with the clearing and upkeep of garden plots and rice ponds, overseeing cash crops, grazing animals, going on trade journeys, building homes and work shelters, and managing their own rice lands. Husbands also have the critical role of representing the household and promoting its interests with respect to other homes and to the village as a whole. Through cooperation and companionship a couple aim at increasing the prosperity and status of the household, something usually measured by harvest surpluses, landholdings, sound health, number of children, and displays of generosity.

While the bela relationship is a culturally acknowledged ideal, it is not unusual for it to be troubled with tension and asymmetry. First, and without 
exception, mappurondo men marry women several years their junior. Thus, a non-gendered axis of prestige and authority based on age enters into the bela relationship, compelling junior wives to show deference to senior husbands. Owing to their seniority, husbands may be said to enjoy an edge of control over their wives.

In the meantime, a strong preference for uxorilocal post-marital residence and hamlet exogamy work to dampen the privilege and control that comes with a husband's seniority. Because they play a large role in shaping domestic and village politics, these preferences are worth examining in some detail. To begin, hamlet exogamy and uxorilocal residence promote the formation of "immobile" mother-sister-daughter cores in each hamlet. It is not surprising, then, to find women symbolically associated with the social continuity and material prosperity of the hamlet (rather than the village as a whole). The deity Tomemana', it will be recalled, is a female figure that watches over ancestral bequests of land and hearth. When opening her first household (within or nearby her parents home), a wife takes coals and ashes from her mother's hearth and puts them in her own. Similarly, a mother is thought to pass on language to her children. And when someone dies, it is the deceased's mother, sisters, and daughters who watch over the body beside the centerpost of the house prior to burial. Brothers and sons, meanwhile, are married off to other hamlets. Husbands are thus "outsiders" and "envoys" who forge social and political links between the hamlets that make up a village. As is suggested by the figure of Debata Tomeola, the masculine spirit of journeys, local symbolism links men with travel and motion - with good reason. Husbands often make a daily routine of hiking across the village to visit their natal hamlet. Further, articles of bridewealth (somba ["honor"]) presented to the bride's family by the groom's relatives usually consist of cloth and tools obtained on trade journeys to the coast.

In the sphere of domestic politics, a young husband is said to "live beneath the ends of the floorbeams" of his wife's natal home and must be careful not to place excessive demands on his spouse. Obliged to help his in-laws, he rarely wins more than marginal status within their household. In addition, the need to stay in favor with his in-laws is crucial to the new husband in that the former are the persons with the greatest influence on his wife. If a husband falls into disfavor with his in-laws, the latter may try to persuade their daughter to seek divorce (a relatively easy matter), with the consequence of undermining the husband's status as an adult male. Thus, a husband's best chance for holding onto a wife and commanding her services is to subordinate himself to his parents-in-law. That they are older can make this task a bit easier, but all too frequently the situation breeds tensions and complaints. For their part, wives may show some ambivalence toward their husbands, especially if there have been clashes with her 
parents. This ambivalence also finds expression in the household rite known as melambe, in which women attempt symbolically to expel the husband from the house (more on this later).

Village endogamy, hamlet exogamy, and uxorilocality also shape the way women and men participate in village politics. By virtue of their role in local social structure, married men have to become village politicians. Their interests and obligations span natal and affinal households as well as natal and affinal hamlets. Women have more narrow political interests, ones that focus on their natal hamlet and show deep commitment to the social bonds of mother-sister-daughter cohorts. As a result, locals think of the village as a male sphere, and the hamlet and household as female spheres. Positions of village leadership ( tomatuatonda') customarily fall to men, and the voices heard in gatherings to discuss village affairs are those of men. In principle, women may take part in these discussions or sit as village head. But for a woman to do so would strike villagers as peculiar and would certainly be a case of "beating the odds" (cf. Atkinson 1989, 1990, from whom I borrow the phrase). Beyond the rule that "village" rituals performed under the authority of men must take place before the household prosperity rites overseen by women, there is little evidence that the male-dominated village sphere is consistently valued above the female-dominated hamlet/household spheres. I would suggest, then, that gender asymmetry in village-level political life may not be so much a matter of hierarchical value (male over female, public over domestic) as a matter of political scope. The village politics of men encompass the socially and residentially limited politics of women, but are not consistently accorded higher value. ${ }^{4}$

What is the substance of village and hamlet politics? In the gatherings of male peers and elders, dispute settlement, succession to political and ritual offices, relations with the civil administration, and the coordination of ritual actvity are key topics. Yet these matters are invariably caught up in struggles for prestige among men. Within this snare of village politics a husband tries to protect and advance his own status as well as the interests of his household and kin group, largely through oratory and intrigue. Above all, village politics comprise the arena in which men try to maintain parity and cement their claims to a wife, hearth, and household. Not surprisingly, wife-stealing is a dreaded and explosive issue, for the theft of a spouse undermines a man's prestige and status as a male peer. ${ }^{5}$ Women, to be sure, are interested in the course of village politics and never forfeit their stake in local issues. But they ordinarily do not take a direct and public part in resolving such issues. Their authority seldom reaches beyond the affairs of hamlet and household. Too often a pawn to be controlled in male prestige competitions, a woman lacks experience in wielding political power in confronting and cooperating with groups of men. That being the case, it is not surprising to hear men remark 
that women lack an understanding of village issues, or are without guile. Men, on the other hand, think of themselves as cunning and conniving, always ready to lay plans to gain advantage over one another. Women, meanwhile, often view men as troublemakers whose prestige interests threaten the calm and stability of the household.

Village issues and prestige politics obviously touch the household and hamlet, especially through the bela relationship. Nonetheless, hearth and hamlet are the key sites for the sacred politics of prosperity, religion, and ritual. While both husband and wife share a concern for the material prosperity of the hearth and family, the latter is felt to be the guardian of household welfare. Her capacity to bring a providential presence into the home by being possessed or "taken by the debata" (diala debata) during ritual accords a wife and mother a signficant degree of religious dominance, and places her at the threshold of the sacred. Men, meanwhile, play a more peripheral role in the religious management of household prosperity.

It should be clear, then, that the bela relationship brings together two gender-specific concerns: a husband's worldly preoccupation with male prestige and village affairs, and a wife's marked involvement in the sacred guardianship of household prosperity. ${ }^{6}$ At an ideological level, the bela relationship is one of egalitarian complementarity, a melding of the worldly and sacred. Of course, it is difficult to make out exactly how a woman experiences her alienation from village politics or how a man feels about his peripheral role in the sacred activity of the homestead. Yet a broad look at these gender differences finds grounds for collaboration rather than flashpoints for conflict and turmoil. Indeed, the bela partnership between husband and wife subsumes and balances these differences, and even thrives on them. At the same time, a husband has a tactical need for a wife and hearth if he is to hold his own in the prestige politics of men. A husband thus can be expected to take steps to control his wife and her services, whether through his in-laws or through his ability to flatter, sweet-talk, or command. To the degree that he succeeds, the bela partnership takes on an asymmetrical character. Again, women's ambivalent feelings about the asymmetries of marriage do find expression in ritual. As for a wife's everyday tactics in responding to marital inequities, these can run from agreeable submission to silent protest, and on occasion, to flight. Above all, a woman can resort to divorce, or the threat of divorce, to put a check to her husband's capacity for domestic control.

To sum up, the gender differences and sexual politics of the mappurondo community tend to resemble those described by Jane Collier and Michelle Rosaldo in their study of hunter-gatherers and simple horticultural societies (1981). Furthermore, they fit reasonably well with patterns described for other bilateral "hill tribes" in island Southeast Asia. Overall, we find in 
mappurondo culture a fairly egalitarian gender ideology that stresses the complementarity of women and men. If that ideological system posits differences between men and women, it nonetheless fails to organize the distinctions into a stable hierarchy of value wherein one gender could be said to be consistently subordinate to the other in terms of prestige. ${ }^{7}$ With the exception of certain ritual practices (to be described), very little effort is expended to police the boundaries of gender difference in daily activity. Asymmetries in authority do exist, but for the most part reflect a relational structure that puts emphasis on men in some contexts, and on women in others. Like the Wana in the eastern central region of the island, men emerge consistently as village leaders. But this edge of authority is offset by woman's privileged role in the realm of the sacred. On the other hand, clear vectors of asymmetry appear in marriage, idealized as the egalitarian and complementary bela relationship. Here, a husband's anxieties about male prestige and peership lead him to find ways to control his wife and her domestic and sexual services.

\section{Ritual and Ritual Music}

As I stated earlier in this article, ritual gives the mappurondo community practical and ideological focus. Of course, the centrality of ritual life in this community is no guarantee that ritual will mirror the pattern of everyday social relations, or that ceremonial theater will set the stage on which the social whole is played out. By the same token, it would be wrongheaded to presume that ritual encapsulates the entirety of mappurondo sexual politics. Although framed so as to be distinct from the everyday, ritual practices may be said to comprise a part of social reality rather than merely reflect it. Thus, more fruitful is a view that sees in ritual select practices and commentaries that shape cultural knowledge and social experience. This is not to insist that rituals must at all points and in all contexts convey a deep cultural and practical wisdom (cf. R. Rosaldo 1984), but only to argue that analysis must look for significant points of connection between the ceremonial and the everyday, and then inquire as to the character of those ties.

Mappurondo rituals place an enormous emphasis on gender difference, nowhere more so than in ceremonial musics. I should underscore the importance of vocal and instrumental music in the ritual order. In this hill society, music is not an aesthetic frill on practices more serious or consequential. Rather it is a mode of social practice through which spiritual potency and well-being are made manifest. Music is here so powerful and dangerous that a very rigid set of tabus constrain performance. All musicmaking takes place in ritual settings, whether in ceremony proper or during somewhat broader periods of ritual time. With the exception of funerary 
musics, all instrumental and vocal performance is limited to less than two months out of an eleven or twelve month harvest year. So long as no one passes away, mappurondo households spend up to ten months in "musical silence." Specific genres of song and instrumental music-including rehearsal or the mere mention of certain lyrics-may be heard for only a few hours or days. Control of the village soundscape is paramount, for musics out of place can summon spirits when they are not wanted, disrupt labor that should be devoted to the rice crop, and elicit inappropriate emotions and anxieties in a time intended for calm. Further, musics out of place count among the most serious points of conflict between mappurondo villagers and their Christian and Muslim neighbors, persons who are not bound by ancestral tabus. Social and ideological camps struggle for musical domination of the village.

Just as there is a sexual division of labor in this society, so, too, is there a gendered organization of musical practice. Additionally, vocal and instrumental musics make explicit and implicit comment on gender differences and male-female relations. Further, the rigid tabus that surround and constrain ritual music effectively and closely police the musical production of gender distinctions. Music-making thus plays a significant rather than incidental part in shaping, defining, and calling forth gender differences. The questions to be asked, then, are how different genres of music support or threaten predominant ideas about gender and how music itself may be part of local sexual politics.

\section{Gender and Ritual Organization}

Villagers borrow an image from women's ceremonial garb to talk about ritual events and tabus: a necklace of four strands. The strands correspond to four different kinds of rituals: those having to do with the planting and harvesting of rice; those concerned with death and mortuary practices; those connected to marriage; and those included under the brief but exuberant period known as pa'bisuan, the time of quickening spirits. Male-female symbolism shows up in most rituals, but nowhere more so than in the postharvest rites of pa'bisuan, where it deeply colors local understanding of manhood (kemuanean) and womanhood (kebainean). ${ }^{8}$

Very generally, the organization of pa'bisuan draws from contrasts between the village sphere dominated by men and the household sphere of women. Villagers carve up pa'bisuan into two domains, one male ( $p a^{\prime}$ 'bisuam muane), the other female ( $p a^{\prime}$ bisuam baine), according to whether it is men or women who are to act as focal participants and authorities. Irrespective of who holds authority, both men and women freely take part in ritual throughout pa'bisuan. Ritual performed under the authority of men concerns the village as a whole and starts up a few weeks after the newly harvested 
rice has been put in storage. The rites must be completed before women's ceremonies may take place. Men's ceremony is limited largely to pangngae, the ritualized headhunt that is run in purely symbolic fashion; that is, real heads are no longer taken (see George 1989, 1991). After pangngae has come to a close, individual households may conduct prosperity rites through the authority and knowledge of women. The latter ceremonies are especially elaborate and stunning in their symbolism, and some may take as long as a month to complete.

\section{Gender and Ritual Language}

Gender differences also shape the language of ritual. For example, the speech and song lyrics of men's rites are in common tongue and are readily understood by all. For men and the women who sing with them during pangngae, words are always of this world; their words are always their own, or in liturgy, the words of ancestors. Women's ritual, on the other hand, relies at key points on esoteric verse taken from waters believed to flow from the skyworld. It works like this: the debata sing or recite words into streams that feed the rivers of the upland world. When it comes time to hold household rituals, female specialists go upstream from the village and draw water from the river. Just prior to the ceremony, the specialists and all members of their chorus will each take a sip of the water and so drink in words to the arcane songs and chants to be performed. In contrast to the talk and song of men's ritual, the mysterious chants of women's ceremonies can rarely be understood by villagers. Trance-talk, too, is a specifically female speech form. Entranced speech (in contrast to entranced song) is almost always in Mandar, the tongue of coastal dwellers to the west and south, and usually takes place when a spirit wishes to criticize ritual practices and attitudes through the voice of a woman.

The critical difference, then, between men and women's ritual speech and song is that in genres associated with men it is the speaker who speaks, whereas in the genres associated with women, the speaker is being spoken through by gods and spirits. Ritual language thereby marks something of a reversal with respect to the position of women and men. Women, it will be recalled, anchor the social order to hamlet lands and to the local past. Men are on the move-whether between hamlets or to more distant places such as the forest or the coast. Yet the language of women's ritual genres is exogenous, having sources in the skyworld or on the coast. ${ }^{9}$ The language of men's rites, on the other hand, is the local village tongue.

The contrast between speaking and being-spoken-through also colors the aesthetic criteria by which performance is judged. Virtuosity in the context of men's ceremonies lies in the active control of speech and song genres. Virtuosity in the context of women's ritual, however, comes with 
abandoning control and making oneself receptive to the language of the sacred waters. The villagers' own explanations may help clarify and discriminate between the different aesthetics. The performer in a men's rite must be like a person felling a tree-a task that falls to men. Cut correctly, the tree falls "into the village" (loe tama ri bamba) and subsequently may be used and enjoyed. Cut incorrectly, the tree falls "into the river" (loe tama riuai) and is washed away. Giving a speech or leading a song, a person must "cut" the text-its metaphors, its rhythm, its tunefulness—in the right fashion to be effective. The specialists in women's ritual are not thought to consciously shape their performance. Rather, their chants are supposed to "flow like water" under the guidance of the spirits and thus must be done in a fluid and uninterrupted manner. Should a woman falter while chanting, it is a signal that the spirits are displeased and that misfortune will fall upon the household.

In sum, the ideology of ritual speech and song distinguishes male and female modes of performance, linking masculine genres with control and everyday language and feminine genres with receptivity and exogenous languages. To speculate a bit, I think it likely that this ideology of performance captures something of the sexual politics that shape the bela relationship. It seems hardly an accident that the control of language is associated with adult males, the very husbands who try to control their wives. And just as entranced women give themselves over to exogenous languages and voices, so too is it hoped or expected that wives will give themselves over to the wishes or commands of their husbands, the "strangers" from another hamlet who intrude into the household. At the same time, this ideology potentially undermines the power and authority of husbands. By yielding to the words and voices of distant beings, wives momentarily can escape the "common code," the village language in which the prestige politics of men dominate.

\section{Instrumental Music: An Exclusionary Practice}

The theme of male control prevails very markedly in instrumental musics. Drums, flutes, rattles, and the dulcimer-like kacapi are in the hands of men and men alone. Men make them, care for them, and play them. Kacapi and rattles are few and along with the delicate bamboo flute (sulin) have little or no place in the rites of pa'bisuan. Accordingly, my discussion will concern the drum (ganda or gânda) and the large bamboo flutes called tambola. ${ }^{10}$

The tambolâ is emblematic of pangngae and the headhunter's journey to distant lands. It is the task of each warrior to pause at the edge of the forest and make a tambolâ before returning to the village, being careful not to let any woman see him making the instrument. (It is said that should a woman 
happen by and look, she will fall fatally ill. $)^{11}$ Roughly a meter long, three inches in diameter, and decorated with plaited sugar palm leaves, the tambolâ produces an eerie, low-pitched tone. Slipping into the village in the dead of night, the headhunters startle the hamlets with shouts and loud blasts on their tambolâ. The sound of the tambolâ marks the beginning of pa'bisuan - the time of quickening spirits—and formally releases villagers from mourning and the tabus of silence. Key to the celebration of manhood, the tambolâ are described in song as stirring joy, astonishment, and desire in the hearts of women.

Drumming, meanwhile, is fundamental to the ritual control of women and spirits during pa'bisuam baine. Drum rhythms not only summon spirits to the ritual household, but also "hold onto" entranced women as they dance. Once again, male control and female receptivity are the criteria for performance. The women's rite known as malangngi'show these principles at work. During malangngi', a cohort of women and girls steals out of the hamlets in an upstream direction. At the edge of village lands they climb up into a banyan tree and onto a platform built especially for this ritual. While up in the tree, they become possessed by debata and are said to turn into birds as they dance. ${ }^{12}$ Panicked by the absence of their wives and daughters, village men launch a search and eventually discover them up in the banyan. A few men are sent to fetch drums. Upon their return, ritual specialists (sando ganda) play set dance rhythms for the possessed women and after a time, "drum them down" from the banyan. Climbing onto the backs of their husbands and fathers, the women ride back to the village and ascend into a house where they dance until the following morning. When I discussed this rite with one of the drummers, he remarked that if the drums were not played, "our women would stay as birds and fly off into the forest. They wouldn't come back."

More emphatically than the patterning of ritual language, the instrumental music of the mappurondo community associates receptivity and control with women and men, respectively. The low howling tones of the tambolâ are a symbol of manhood and male prestige, intended to spark a desire that will overcome a wife or lover. If the tambolâ is a means for drawing a woman near, the drum is an instrument that prevents women from abandoning their mates. Once more sexual politics are transposed to the realm of music. A husband's anxiety about losing a wife-the very source of his prestige as an adult male-echoes in the beating drum.

Woman's exclusion from instrumental music is among the most striking and rigidly policed gender differences in this hill society. The severe tabus that prevent women from playing instruments, that deny them no small degree of control over their own ritual experience, appear the product of masculine anxieties about abandonment and a woman's intimate knowl- 
edge of sacred power. The asymmetries of marriage and instrumental music - the latter itself a form of social relationship—-ellingly point to the subordination of women.

\section{After the Drumming Stops: Vocal Music of Mystery and Protest}

In the household rites of pa'bisuam baine, drumming and the choral music of women are never coincident. The drum must be silent before women will sing. The voices of men, too, are for the most part silent: they never sing during household rites. So long as drumming is not called for, men take but a background role in household rituals. Sitting off to the side of the house, they are excluded from the songs and chants led by female specialists (sando baine). Does their exclusion from the song of household ritual amount to the momentary subordination of men to women? Does it counterbalance the tabus that prohibit women from playing instrumental music? I think not. While men clearly defer to the authority and place of women in running household rituals, they do not succumb to the songs of the ritual specialists. Rather, they sit aside and watch, unless called to play the drum. The drum and (to a degree) the flute, meanwhile, are meant to hold women in sway. A supposed balance between these complementary practices seems doubtful, insofar as the element of submission is so lacking in men's exclusion from the songs and chants of household ritual.

Most of the vocal music heard in household ceremonies is choral. As mentioned previously, it falls to ritual specialists to bring the songs to the house with sacred waters collected upstream, and to then lead the chorus or choruses of women in singing. Lyrics are peppered with words from distant upland languages and dialects, and may contain archaic constructions. There is also evidence to suggest that phonemic alteration comes into play to "mask" everyday words. Thus the songs strike villagers as exotic and arcane. While everyone knows what the songs are about and what the songs do, very few persons have a word-by-word grasp of a song's lyrics or meaning. Most are songs of praise that glorify the wife, the husband, the rice crop-persons and things that make up a household.

Women thus give voice to a language of awe and mystery by way of songs that exalt the sources of household prosperity. Yet the women also sing of evils and misfortunes that must be cast out of the household. This takes place during the rite known as melambe. A tree made of banana stalks, sugarcane, sheaves of rice, stalks of cordyline, and plaited sugar palm leaves is erected in the house directly over the centerpost. Women dance around the tree for many hours singing songs of praise. Around midnight, the women stage several skits all having to do with misfortunes of one kind or another: the theft of a wife, the birth of an illegitimate child, being overcome by cold, breaking the tabu against a woman watching a man tap palm-wine, 
and the inadvertent killing of a chicken. Each skit has a song lamenting the misfortune that has taken place. Through drama and song the misfortunes are attached to the tree. Towards dawn, the tree is chopped down and female specialists begin mangngarimbâa' ("flinging out") with a song performed in everyday language. While taking up pieces of the tree and throwing them out the door of the house, the women sing:

Lakusakummi kusakum
lakurimbâ' sau' Daba
angga tindo kadakena
angga pabi-pabianna
angga sarimbu'bu'anna
kupasule lau' mai
tendenganna sumange'na
angga nabua' indona
kaju bau' di tibojong
kaju katangka ri langi'

Lakusakummi kusakum lakurimbâ' sau' Daba angga tindo kadakena angga pabi-pabianna angga sarimbu'bu'anna kupasule lau' mai tendenganna sumange'na kaju bau' di tibojong kaju katangka ri langi

No sooner do the women throw out the remains of the tree than they grab hold of the senior drummer (who has served as the "ritual husband" during the ceremony) and begin to drag him toward the door with the idea of tossing him out with the other misfortunes. A comic tug-of-war takes place for a few moments as the drummer resists. It ends in a draw.

That the song of mangngarimbâ' makes use of everyday rather than arcane language underscores women's ambivalence about their husbands. Everyone is to understand the nightmare and burden of a husband's presence as well as his indispensable role in the household. Yet even if the sexual politics of the bela relationship come out in the open in the vocal music and dramatic action of mangngarimbâ', there still seems little prospect for change. The ritual critique of a husband's presence in the household may vent a spouse's frustrations, but in the end makes given woman's inability to discard him.

The vocal and instrumental musics of pa'bisuam baine mark the household as a site of reciprocal exclusions, exclusions that shape a person's experience and understanding of gender differences in the domestic sphere. The differences are complementary, but also carry with them some of the anxieties and inequities of the bela relationship. In the ritual frame, these anxieties and disparities do not reach an explosive level, nor does their formulation appear to challenge the social order. For better or worse, they are kept in productive tension.

\section{The Sumengo: A Vocal Genre of Inclusion}

Discussion so far has dealt largely with the musics of household ritual, musics associated with the encompassed realm of women, hearth, and 
hamlet. What about the ritual music of the encompassing - the "masculine" sphere of the village-performed in the headhunting ceremonies of pangngae? Along with woman's lack of voice in everyday village concerns, the centrality of men's prestige politics in village affairs might lead us to listen for a music that excludes women. Interestingly, this is not the case. The sumengo, by far and away the most prominent and important song genre in village headhunting ritual, includes both men and women as performers. That headhunting ceremonies are largely a sumengo-fest suggests that this inclusionary genre offers a crucial glimpse at what male prestige and village politics are all about (see George 1989, 1990, and forthcoming). Recalling that male prestige and peership make it imperative that a man have a wife, it is my view that sumengo performance draws upon (and promotes) a select vision of the bela relationship wherein woman's presence is idealized in line with male interests.

Generally speaking, the sumengo are about headhunting journeys and the ceremonies that follow. The lyrics are in everyday language and performance is choral. Furthermore, verses are remembered rather than invented on the spot; no one in my acquaintance showed an interest in composing new songs. The songs are usually performed by small groups of men or women, each led by a tomantokko, ${ }^{14}$ a male or female performer skilled in remembering different song texts and rendering the vocally difficult solo phrase that begins them. After the tomantokko opens with a strained, high-pitched phrase of eight syllables, the chorus of men or women join in with two extremely slow eight-syllable phrases sung at lower pitches.

When singing, groups of men and women commonly take turns, the men singing one sumengo, the women singing another in response, and so on. At the same time, it is clear that some lyrics may only be sung by women, others only by men. Thus, both performance patterns and song content suggest that gender differences are crucial to the genre. Further reflection invites another discrimination: it is not simply men and women performing the songs, but more specifically, groups of husbands and groups of wives singing to one another. Insofar as this is true, performance pattern and lyrics configure and comment upon the bela relationship.

At one level, turn-taking reveals a playfulness and a complementarity between husband and wife. ${ }^{15}$ In some villages, a chorus must be allowed to finish its song before another begins. In others, villagers perform the sumengo as overlays, one simultaneously on top of the other, producing what singers describe as a pleasing cicada-like effect. ${ }^{16}$ Singers talk about choruses "stepping on one another" and about men and women competing to outdo one another with clever songs. Sumengo performance patterns thus comprise a game that draws husbands and wives into a playful race of song and counter-song. ${ }^{17}$ 
Sumengo-play also has something to do with knowing an appropriate sequel or rejoinder to the preceding song. For example, a chorus may pose enigmatic questions and riddles, as when men ask:

\section{Diattomokoka' iko mogasin tandiulanni muondo pitu bulanna}

\begin{abstract}
You, have you ever played at it making tops spin but without string they whir and hum for seven moons
\end{abstract}

Taken literally, the "problem" is figuring out how one could spin a top without using string and make it twirl for an inordinately long time. The women reply with a conventionally spare answer that conceals the figurative solution:

$\begin{array}{ll}\text { Diattomakantekami' } & \text { Yes, we have indeed played at it } \\ \text { mogasin tandiulanni } & \text { making tops spin but without string } \\ \text { muondo pitu bulanna } & \text { they whir and hum for seven moons }\end{array}$

What may seem like an evasion is not. The women know that the headhunter is the stringless top. Just as a top may spin away for a moment and then return to hover in front of the person who cast it into motion, the headhunter goes off from the village and then comes back to celebrate for the seven nights of ceremony that make up pangngae. In short, the sumengo amount to a game of knowledge. The male and female tomantokko must know what questions to pose and what answers to give. But the game of knowledge is also a game of power: To pose questions is to exact a hold on another, to give answers is to escape that grasp (see Canetti 1978:284-290, Huizinga 1950). Seen in this light, husbands and wives are playing for power and control over one another during sumengo performance. Yet neither achieves dominance except for a few fleeting moments. The conventions of sumengo performance are such that husbands and wives strike a balance with one another in the gaming of question and answer, image and counter-image.

As they chase one another with their songs, husbands and wives capture some of the playfulness and balance that arguably may color a bela relationship. But something else is afoot, too. A significant number of songs play on the themes of sex and desire. For example, women have a sumengo that goes:
Ta'bu sure' mane dadi mane lulangam allona Striped colored cane just coming up just starting to reach for the sun paneteanna kaloe' the parrot's dance along the branch

The lyrics convey the restless, straining desire of women (here, a parrot's dancing movements on a branch) when they look upon a handsome, mature headhunter (striped sugarcane). Men sing a song in which an unmarried man looks for a lover: 
Umba tambim muongei umbam pellullabeammu
Where is the room in which you rest where is your shuttered window

onimmu mandang kurangngi' I can hear nothing but your voice

Some lyrics evoke erotic scenes, as in a song I once heard women perform:
Mane belue' sitambem
mane appu' silolonni
Hair just beginning to tangle sweat begins trickling together
anna ummoniram manu'
then the cockerel must be singing

Tangled hair and rivulets of mingled sweat provide the image of sexual union, the singing cockerel, an image of the headhunter's phallic excitement and pleasure. In contrast to imagery of sexual confidence and prowess, there are also expressions of masculine anxiety. In particular, a few sumengo reveal a husband's worry about his desirability. One goes:

Menna' lamuala
kandean tadiampalla'
anna pindam pebajoan
Which do you want to take the coarse unpolished wooden dish or the porcelain reflecting bowl

Here the men sing to their wives, asking whether the latter would rather have a humble item found in mountain villages or one of the more elegant wares kept in coastal settlements (the traditional home of the headhunters' victim). The chorus of wives replies with a song in which they choose the item associated with their husbands:

Arabopinea
kandean tadiampalla'
anna pindam pebajoan

Moments later, the men begin a similar exchange with their wives:
Better that I just keep the coarse unpolished wooden dish than the porcelain reflecting bowl
Menna' lamuala
labuju pettanetean
anna londom belo tondo'
Arabopinea
labuju pettanetean
anna londom belo tondo'

\begin{abstract}
Which do you want to take the wild cockerel from the mountains or the hamlet's fancy rooster

Better that I just keep

the wild cockerel from the mountains than the hamlet's fancy rooster
\end{abstract}

Clearly, then, the playful song-banter swells back and forth with undercurrents of male anxiety and erotic will, as well as with waves of feminine desire and reasssurance.

At this point a troubling question has to be asked: Whose version of woman is this? The feminine image depicted in sumengo performance is that of a woman who desires a man, who offers reassuring words to her spouse, and who likes playful sexual banter. It is an image of woman as men would 
like her to be, an image that obscures (and perhaps denies) possibilities for her own subjective presence in the social order. If the sumengo is an inclusionary genre that projects the complementarity of women and men, it nonetheless appropriates the feminine so as to exalt and construct a manhood reflecting the prestige anxieties of men. In short, women's inclusion in sumengo performance is neither innocent nor unmotivated. While sumengo lyrics are not authored by men, they still trace the reach of masculine discourse.

As a final note, it is worth remarking that women's sumengo performances represent the key instance of woman's voice in village politics. Normally excluded from everyday participation in political discourse, a woman is drawn in under traditional ritual constraints and allowed to speak, not with the free authority of her own experience but, rather, with the purpose of turning man's gaze back on himself.

\section{Concluding Remarks}

The foregoing analyses show that gender ideology and sexual politics in the mappurondo community are much like that of other Southeast Asian hill societies such as the Ilongot (Rosaldo and Atkinson 1975) and Wana (Atkinson 1990). To review, ideas of human sameness, a significant range of egalitarian principles, and a set of basic prestige criteria unrelated to gender tend to level or balance gender differences such that neither male nor female is accorded higher social value in systemic fashion. Further, villagers see gender differences largely in terms of complementarities, even when requiring exclusions that promote differential realms of authority. At the same time, the strains and asymmetries of sexual politics haunt local notions of male-female collaboration, complementarity, and balance. In particular, men's anxieties about male prestige and peership spark a deep concern for controlling women through marriage and the bela partnership. To a degree, mappurondo gender ideology not only lies disjunct from the relationships and strategies of power in marriage, but also mystifies them. Similarly, local discourse about gender downplays or overlooks woman's alienation from the political and man's alienation from the sacred. Last, the disparities in power and authority lying between men and women seldom provoke challenges to the social order. Indeed, they appear unquestioned by men and women alike even when their presence is exposed.

I have said nothing about historical transformations in the mappurondo community, and have thus given a fairly static portrait of how gender "works" there. Change has taken place and will continue to do so. For example, wifestealing was largely a concern of generations past. It rarely takes place today. During the last few decades, then, villagers have witnessed the relaxation of a core strain and strategy in men's prestige politics. The civil administration, 
meanwhile, has shown a programatic interest in eliminating multi-hearth houses. While the high incidence of uxorilocality persists, villagers have incentive to more rapidly open independent homesteads or to risk a strategy of neolocality. One would reasonably anticipate changes and new tensions in domestic politics. Perhaps most significant, the pressures of a market economy have made it far more burdensome for villagers to undertake the elaborate household rituals run under the authority of women. The rites now take place infrequently, with the consequence of undermining women's authority and voice in the realm of the household. The headhunting ceremonies of pangngae have been left to become the focal center of mappurondo ritual life. Relative to women, men today have greater ritual prominence than they did in the past. Their headhunting rites are a rallying point for mappurondo identity and a focal site for resistance against more powerful social and ideological orders.

The realm of ritual music in the mappurondo community proves to be broadly coherent with local ideology and practice when it comes to gender. While ritual and ritual musics tend to push gender difference to a radical degree, and at times demand crucial exclusions, they nonetheless fail to disturb the hegemonic patterns of understanding and practice. In fact, from the vantage point of Koskoff's scheme the music of the mappurondo community may be said to maintain in constitutive fashion the established social/sexual arrangements, even while permitting wives a space for symbolic protest against men's intrusive efforts to dominate the bela relationship (1987). A counter-hegemonic music is absent. At this moment in time, subversion and critical appraisal of local gender relations must be sought in non-musical practices or in forces that impinge on the mappurondo community from without.

In closing, this coherence between ritual practice and the dominant patterns of everyday thought and action is not that surprising. Ritual practices in the mappurondo community, as in several island Southeast Asian societies, radically formulate gender as a difference that does make a difference. If ritual music in these societies is a form of symbolic power, a means of constituting "the given" (cf. Bourdieu 1991), then such music can only support hegemonic patterns because of its tendency to make certain gender distinctions unassailable. In the mappurondo community, a counterhegemonic music would necessarily be a non-ritual music. And such music is tabu. Bearing in mind that ritual performance is the necessary basis of mappurondo identity and polity, it is important to see that the ceremonial order puts music and sexual politics at the heart of this minority religious community. To the extent that parallels can be found in other societies in the region, the study of music-making and gender will be of enormous analytic and comparative significance. 


\section{Notes}

Funding for the three years of research (1982-85) that led to this article came from several sources. I gratefully acknowledge support from the Social Science Research Council; the Fulbright-Hays Doctoral Dissertation Research Abroad Fellowship Program (Project No. G0082-00543); the Wenner-Gren Foundation for Anthropological Research (Grant No. 4144); and the Horace Rackham School of Graduate Studies at the University of Michigan. I am also indebted to my Indonesian sponsors at LIPI and PLPIIS-UNHAS and to the people of Desa Bambang (Kecamatan Mambi, Kabupaten Polmas) for their cooperation. Songs of thanks go to the following persons for their helpful comments while this paper took shape: Kathleen Adams, Randy Baier, Judith Becker, Barbara Hampton, René Lysloff, Vida Mazulis, Sherry Ortner, Pamela Quaggiotto, Mary Steedly, Jeff Titon, Jane Wellenkamp, and Aram Yengoyan. An earlier version of this paper was presented at the 1987 Annual Meeting of the Society for Ethnomusicology in Ann Arbor, Michigan.

1. See George 1989 for a detailed account of my field study in this region.

2. In some cases, these "seductions" no doubt involve having sex with a young woman over her protest and resistance.

3. Jane Atkinson reports that the Wana of eastern Central Sulawesi also use the term bela to denote husband and wife (1990). In the Wana case, too, the term is unmarked for gender. In each case, the term implies that the husband-wife relationship shares formal, functional, and moral features with the ties appearing within unisexual cohorts and task groups.

4. For theoretical debate over male/female, public/domestic, and encompassing/encompassed hierarchies, see Ortner 1990; M. Rosaldo 1980; and Yanagisako 1979.

5. Wife-stealing and the seductions that take place during adolescence suggest that sex with a woman can be seen as a "theft." In both cases, sex with a woman is "stolen" from those who control her-her husband, her father and her brothers. See Ortner 1981 for a discussion of "sex as theft."

6. See Ortner 1974, Ortner and Whitehead 1981, Rosaldo and Atkinson 1975, and Sanday 1981 for different (and somewhat dated) discussions on how sexual hierarchy may relate on a universal basis to sacred and secular domains.

7. If I am correct in my assessment, the mappurondo case weakens any claim that cultural assertions of male dominance are universal.

8. The term bisu appears to be related to bissu, the lowland term for those transvestites whose spiritual potency allows them to play a key role in Bugis ritual. As noted earlier, uplanders often distinguish the bisu or "quickening spirits" as bisu muane (the bisu of men) or bisu baine (the bisu of women). To follow Errington's remarks on the Bugis term (1989, 1990), I would suggest that bisu implies not only a kind of sexual ambiguity, but also and more precisely, an ungenderedness, the potency of which owes not to a conflation of sexual dualities, but rather to the "unbroken unity" implicit in pre-difference.

9. How women learn coastal language or the mysterious words of the debata is a matter kept secret from me. This exogenous language is basic to local ideas about womanhood and knowledge of its "inner workings" usually is withheld from men. A woman doing ethnographic fieldwork in the mappurondo community would be in a better position than I to learn something about how this ritual language is learned, shared, and remembered. vowel.

10. An orthographic note: "a" represents the low back vowel, while "â" marks the low front

11. The dread (secret?) of phallic imagery is unmistakable. A similar tabu prohibits women from watching men tap palm wine. In both instances, men shape a phallus-like instrument. From these pour either a cloudy wine (the palm tap), or a spray of plaited, ribbon-like leaves (the tambolâ). These masculine objects, made "off-stage" (i.e., out of the village) suggest that mappurondo men essentially hide something of themselves from women. In a sense, masculinity depends on differences made and kept in secret, as much as upon differences made visible and audible in ritual performance or everyday life. The same is probably true of women and womanhood; see below. 
12. Most of the dances in pa'bisuam baine are named after birds.

13. The term daba connotes "faraway" or "outside" in addition to naming the island, Java.

14. The term may derive from the verb mentokko, meaning to sit with knee up, a common posture during sumengo performance.

15. My understanding of sumengo performance, here, has been shaped by a reading of John Huizinga's essay on the ludic element in culture (1950).

16. The different performance styles (overlay vs. alternation) have analogues in melodic structure. See George 1989.

17. Here it is worth remarking that I witnessed a different sort of race in a downriver swidden community, but one that may nevertheless shed some light on the sumengo performance. When it came time to plant a rice swidden, youths would take their digging-sticks and rapidly bore holes in the earth. Young women, meanwhile, would cast seed into the holes so swiftly that they would often overtake the youths and cast seed before the boys could dig their holes. Whenever this happened the boys and girls would break into peals of laughter. A contest of this sort was thought to increase the yield of the swidden. The sumengo "contest" per se is not thought to increase prosperity, but headhunting ritual does have the overall purpose of guaranteeing the fertility of rice lands.

\section{References}

Atkinson, Jane M.

1989 The Art and Politics of Wana Shamanship. Berkeley: University of California Press.

1990 "How Gender Makes a Difference in Wana Society." In Powerand Difference: Gender in Island Soutbeast Asia, 59-94, edited by Jane M. Atkinson and Shelly Errington. Stanford: Stanford University Press.

Atkinson, Jane M., and Shelly Errington

1990 "Preface." In Power and Difference: Gender in Island Southeast Asia, vii-xi, edited by Jane M. Atkinson and Shelly Errington. Stanford: Stanford University Press.

Attali, Jacques

1985 Noise: The Political Economy of Music. Translated by Brian Massumi. Minneapolis: University of Minnesota Press. First published in French in 1977.

Bourdieu, Pierre

1991 Language and Symbolic Power. Edited by John B. Thompson, and translated by Gino Canetti, Elias Raymond and Matthew Adamson. Cambridge: Harvard University Press.

1978 Crowds and Power.Translated by C. Stewart, New York: Seabury Press. First published in German in 1960.

Collier, Jane F., and Michelle Z. Rosaldo

1981 "Politics and Gender in Simple Societies." In Sexual Meanings: The Cultural Construction of Gender and Sexuality, 275-329, edited by Sherry B. Ortner and Harriet Whitehead. Cambridge: Cambridge University Press.

Errington, Shelly

N.d. "The Construction of Gender in Southeast Asia: A Call for Papers." Ms.

1989 Meaning and Power in a Southeast Asian Realm. Princeton: Princeton University Press.

1990 "Recasting Sex, Gender, and Power: A Theoretical and Regional Overview." In Power and Difference: Gender in Island Southeast Asia, edited by Jane M. Atkinson and Shelly Errington. Stanford: Stanford University Press.

Feld, Steven

1984 "Sound Structure as Social Structure." Ethnomusicology 28/3:383-410.

Freeman, Derek

1970 Report on the Iban. London School of Economics Monographs on Social Anthropology no. 41. New York: Humanities Press. First published in 1955. 
Geertz, Clifford

1973 "Deep Play: Notes on the Balinese Cockfight." In The Interpretation of Cultures, 45990. New York: Basic Books.

Geertz, Clifford, and Hildred Geertz

1975 Kinship in Bali. Chicago: University of Chicago Press.

George, Kenneth M.

1989 "The Singing from the Headwaters: Song and Tradition in the Headhunting Rituals of an Upland Sulawesi Community." Ph.D. diss., University of Michigan.

1990 "Felling a Song with a New Ax: Writing and the Reshaping of Ritual Song Performance in Upland Sulawesi." Journal of American Folklore 103/407:3-23.

1991 "Headhunting, History, and Exchange in Upland Sulawesi." Journal of Asian Studies 50/3: 536-64.

forthcoming "Lyric, History, and Allegory: Or, The End of Headhunting Ritual in Upland Sulawesi." In Of Heads and History: Traditions of Ritual Violence in Island Southeast Asia and Their Transformations, edited by Janet Hoskins. Berkeley: University of California Press.

Halbwachs, Maurice

1980 The Collective Memory. Translated by Francis J. Ditter, Jr., and Vida Yazdi Ditter. New York: Harper Colophon. First published in French in 1950.

Huizinga, Johan

1950 Homo Ludens: A Study of the Play Element in Culture. Boston: Beacon Press.

Hymes, Dell

1981 "In Vain I Tried to Tell You": Essays in Native American Etbnopoetics. Philadelphia:

Koskoff, Ellen University of Pennsylvania Press.

1987 "An Introduction to Women, Music, and Culture." In Women and Music in CrossCultural Perspective, 1-23, edited by Ellen Koskoff. Urbana: University of Illinois Press.

Kuipers, Joel C.

1986 "Talking about Troubles: Gender Differences in Weyéwa Speech Use." American Ethnologist 13/3:448-62.

McClary, Susan

1989 "Terminal Prestige: The Case of Avant-Garde Music Composition." Cultural Critique 12 (Spring 1989): $57-81$.

1990 "This Is Not a Story My People Tell: Musical Time and Space according to Laurie Anderson." Discourse 12/1:104-28.

Ortner, Sherry B.

1974 "Is Female to Male as Nature Is to Culture?" In Woman, Culture and Society, 67-88, edited by Michelle Z. Rosaldo and Louise Lamphere. Stanford: Stanford University Press.

1981 "Gender and Sexuality in Hierarchical Societies: The Case of Polynesia and Some Comparative Implications." In Sexual Meaning: The Cultural Construction of Gender and Sexuality, 359-409, edited by Sherry B. Ortner and Harriet Whitehead. Cambridge: Cambridge University Press.

1990 "Gender Hegemonies." Cultural Critique 14:35-80.

Ortner, Sherry B., and Harriet Whitehead

1981 "Introduction: Accounting for Sexual Meanings." In Sexual Meaning: The Cultural Construction of Gender and Sexuality, edited by Sherry B. Ortner and Harriet Whitehead. Cambridge: Cambridge University Press.

Peletz, Michael C.

1987 "The Exchange of Men in Nineteenth-Century Negeri Sembilan (Malaya)." American Ethnologist 14/3:449-69. 
1988 A Share of the Harvest: Kinship, Property, and Social History among the Malays of Rembau. Berkeley: University of California Press.

Rosaldo, Michelle Z.

1980 "The Use and Abuse of Anthropology: Reflections on Feminism and Cross-cultural Understanding." Signs 5/):389-417.

Rosaldo, Michelle Z., and Jane M. Atkinson

1975 "Man the Hunter and Woman: Metaphors for the Sexes in Ilongot Magic Spells." In The Interpretation of Symbolism, 43-75, edited by Roy Willis. London: Malaby Press.

Rosaldo, Renato

1984 "Grief and a Headhunter's Rage: On the Cultural Force of Emotions." In Text, Play and Story: The Construction and Reconstruction of Self and Society, 178-95, edited

Roseman, Marina by Edward Bruner. Washington: American Ethnological Society.

1984 "The Social Structuring of Sound: The Temiar of Peninsular Malyasia." Ethnomusicology 28/3:411-45.

1987 "Inversion and Conjuncture: Male and Female Performance among the Temiar of Peninsular Malaysia." In Women and Music in Cross Cultural Perspective, 131-50, edited by Ellen Koskoff. Urbana: University of Illinois Press.

Sanday, Peggy Reeves

1981 Female Power and Male Dominance: On the Origins of Sexual Inequality. Cambridge: Cambridge University Press.

Schutz, Alfred

1977 "Making Music Together: A Study in Social Relationship." In Symbolic Antbropology: A Reader in the Study of of Symbols and Meanings, edited by Janet L. Dolgin, David Kemnitzer, and David M. Schneider. New York: Columbia University Press.

Sutlive, Vinson H., Jr.

1987 "Keling and Kumang in Town: Differential Effects of Urban Migration on Iban Men and Women." Paper presented at the 1987 Annual Meeting of the American Anthropological Association.

Traube, Elizabeth G.

1986 Cosmology and Social Life: Ritual Exchange among the Mambai of East Timor. Chicago: University of Chicago Press.

Tsing, Anna Lowenhaupt

1987 "A Rhetoric of Centers in a Religion of the Periphery." In Indonesian Religions in Transition, 187-210, edited by Rita S. Kipp and Susan Rodgers. Tucson: University of Arizona Press.

1990 "Gender and Performance in Meratus Dispute Settlement." In Power and Difference: Gender in Island Southeast Asia, 95-126, edited by Jane M. Atkinson and Shelly Errington. Stanford: Stanford University Press.

Yanagisako, Sylvia

1979 "Family and Household: The Analysis of Domestic Groups." Annual Review of Antbropology 8:161-205. 